\title{
Studying the Impacts of Globalization on Iranian Education System
}

\author{
Mitra Abdolahi Chahardahcheriki (Corresponding author) \\ Institute of philosophy, Sociology and Law Armenian National Academy of \\ Sciences, Ministry of education, Ahvaz, Khuzestan, Iran \\ Tel: 3-745-515-5134_E-mail: Mitramitra1414@yahoo.com
}

Sakine Shahi

Chamran University, Iran

E-mail: Nshahi2001@yahoo.com

Received: August 29, 2010

doi:10.5539/ies.v5n1p172
Accepted: September 23, $2011 \quad$ Published: February 1, 2012

URL: http://dx.doi.org/10.5539/ies.v5n1p172

\begin{abstract}
The purpose of this study is to analyze the degree of globalization of important indicators of education system in Iran including teaching approaches, educational tools and facilities, curriculums and contents, and education management.

Findings suggest that the situation of Iranian education system has some distance with the globalized level and post modernism and is more aligned with traditional indicators and is stagnant and somehow modernity. Among these indicators, teaching approaches are closer to the globalized level and educational tools and facilities are further than others relative to the globalized standards.

Holding in-service training courses for teachers and encouraging them to obtain higher scientific degrees as well as equipping schools with educational technologies by the help of designating more budget, motivating non-centralized programs, employing graduates of education management fields in order to take charge of management in education system can lead to a reduction in the gap between education system of Iran and the globalized one.
\end{abstract}

Keywords: Education system, Curriculum, Education tools, Management, Teaching, Globalization, Postmodernism

\section{Introduction}

These days, simplification of information dissemination and the role of Information and Communication Systems as the fundament for decision making are inevitably obvious. Fast communication systems available in a short time have been developed so far and this fact consequently, has brought along Globalization and some new circumstances (Shahi et al., 2008).

Ginkel believes that it was about half a century ago when these changes appeared (Ginkel, 2002).

Anthony McGrew and David Held regard globalization as an inevitable process which includes the other processes in itself and results in a fundamental change in the institutional environment and social interactions and power counter acts. (Bagheri, 2000).

Conversely, Madison thinks of globalization as a dynamic of human beings in an advanced form (Madison, 2009). Alberto knows modernity as reaching to an end and the beginning of a new era in which significant changes in the world are noticed changed all are approaching to become a unity (Alberto, 2009).

Gidens defines globalization as transfer of time and place by a human being according to his ability in revolutionizing the means of communication and remote activities (Mehr Alizadeh, 2005).

Charlton and Andreas's regarded globalization as an aspect of a bigger phenomenon named modernism. They also regarded the evolution of many communication complexities in societies in accordance with the rise in the number of inhabitants (Charlton and Andreas, 2006). All these occurrences are the clear resultants of the reality of globalization. Many believe that globalization mandates free action and as a result, various factors including monitoring, hierarchical relations, and management-oriented education management have evolved. This simply stands for the alignment of globalization with post-modernity basics and principles despite the globalization not belonging to any doctrines. In the modern world, post modernism teachings have gained popularity and have led to 
new arguments and discussions in various fields including but not limited to political and cultural in addition to literal aspects namely learning and education (Farmihani, 2010). It seems that Jacques Derrida's deconstructive attitudes have led to prominent evolutions in education system (Derrida, 1987).

And the four principles of Michel Foucault (reversal, discontinuity, specificity, and exteriority) affecting education that has made to change in key elements of education inevitable. .( Bagheri,2000)

As a matter of fact, education system have benefited from the many consequences of globalization. UNESCO named the year 2002 as "Human Globalization". Ginkel believes that the education system is an inevitable factor of this scenario (Ginkel, 2002). The economic and commercial life of nations have been thoroughly influenced by globalization and with the growing global competitive environment and the rapid advancements technologies, the business organizations and business models beside management systems and practices are experiencing changes every now and then. In order to be able to keep up with these variations of the system, the management education requires being restructured and refocused (Mushtaq, 2004). Azad (2010) recently did a research entitled "studying and designing electronic government model" which was performed among the staff of department of education bureau of Ahwaz. His findings included the fact that the most significant problems are mainly due to the difficulties rooted in structural-behavioral aspects in addition to the many ones going back to technological, economical, and cultural origins.

In contrast to what was already mentioned, achieving the needed skills for tackling the challenges ahead of the Iranian education system through keeping the loyalty toward traditional, stagnant, and modernity management is a sad truth (Shahi, 2006). Proportional to the changes occurring in the surroundings, education system of Iran needs to try to reform its structure. Furthermore, realization of these objectives and aligning them with revolutions and evolutions in the environment are among the many responsibilities of a deserved management. Throughout a research by Dr. Sekineh Shahi regarding the open relations of upper education and the necessity of pursuing globalization by Khuzestani Universities, she demonstrated being in a transition and stabilization phase of the studied universities and found out that communication infrastructures are still operating in a mechanical sense rather than the post modern (Shahi, 2006).

This research seeks finding out the globalization rate of Iranian education system (Teaching approaches, Educational tools and facilities, Curriculum and content, Education Management) and attempts to analyze the consequences; for this purpose, the researcher outs time studying the indicators of globalization.

\section{Material and methods}

In the current research, two methods of surveying and document analysis are utilized.

\subsection{Statistical Society}

The statistical society for the current survey is all the teachers and principals of primary, middle, and high schools for all the four districts of Ahwaz city, Iran during 2010, this includes 7465 individuals.

\subsection{Sampling Method}

The desired sample was chosen for the implementation of the survey with questionnaire, by the help of a sample size determination table (Morgan \& Krejcie) with the help of a stratified random sampling proportional with the population of the society that is 357 individuals. The stratified number of sample was evaluated by this formula:

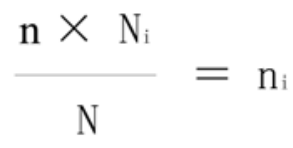

$\mathrm{n}$ : Total volume of the sample

$\mathrm{N}$ : Total number of statistical society of the research

Ni: Population of the class

ni: Volume of the sample

\subsection{Research Tools}

According to the topic of this research, and due to the novelty of the subject, no data collection tool was available. In order to compile the questionnaire, the researcher initially performed a qualitative study and then, using that, a proper questionnaire was compiled for the quantitative aspect of the survey. 


\subsection{Data collection tool}

include demographic information check list, the questionnaire made by the researcher for globalized education system and document analysis.

\subsection{Reliability of Research Tool}

According to Cronbach's alpha, the resulted coefficient for the questionnaire with 30 subjects and 71 indices is $\alpha=90$.

\subsection{Data Analysis}

Quantitative data were analyzed by the help of SPSS 16 application in the two descriptive and illative levels. In the descriptive part, frequency, mean value, percentage, and standard deviation were used whereas, from the illative aspect, mono-variable T-test and independent variable T-test, one-way analysis of variance (ANOVA), and regression were utilized. Data obtained from the documents is analyzed by the help of inductive content analysis.

\section{Result}

From the attitudes of scientists like Foucault and Derrida, Farmahini, and Jiroux, one can perceive some features for the globalization of education in post modern system among which the most important are:

\begin{tabular}{|c|c|}
\hline Indicator & Features of Globalization \\
\hline $\begin{array}{l}\text { Teaching } \\
\text { Approaches }\end{array}$ & $\begin{array}{l}\text { A method based on discussion and argument, dialogue } \\
\text { Communal learning approach } \\
\text { A method based critical Dialogue and analytical skills } \\
\text { Decentralization, de-structuralizing, creative-based } \\
\text { A method based on horizontal relationship between students and teachers }\end{array}$ \\
\hline $\begin{array}{l}\text { Educational } \\
\text { Tools and } \\
\text { Facilities }\end{array}$ & $\begin{array}{l}\text { Audio and visual equipment in teaching particularly the Internet and computers and } \\
\text { equipping schools with laboratories } \\
\text { The availability of excursions } \\
\text { The possibility of changing the decoration of the class }\end{array}$ \\
\hline $\begin{array}{l}\text { Curriculums } \\
\text { and Contents }\end{array}$ & $\begin{array}{l}\text { Evolutionary development } \\
\text { Noticing the individual differences amongst students and communal culture } \\
\text { The possibility of multi-dimensional interpretation of the context and self-creativity } \\
\text { Avoiding general concepts } \\
\text { Uncertainty and constant change of content } \\
\text { Participatory and flexible programmes } \\
\text { Practical and applied knowledge in programmes } \\
\text { Interdisciplinary curriculum }\end{array}$ \\
\hline $\begin{array}{l}\text { Educational } \\
\text { Management }\end{array}$ & $\begin{array}{l}\text { Self-restraint and inner discipline } \\
\text { Decentralization } \\
\text { Research-oriented in particular action researches } \\
\text { Long run goals } \\
\text { People-oriented and applying leadership instead of management }\end{array}$ \\
\hline
\end{tabular}

In order to study the current state of globalization in Iran, the data taken from the questionnaire were analyzed and firstly, these were studied descriptively. Then, it was compared with the desirable situation by the help of using the mono-group $\mathrm{T}$ test. For studying the impacts of demographic characteristics of test subjects on level of globalization, statistical inference for regression, one way analysis of variance and independent group T-test were used.

As it is observed from the table (1), the average and the standard deviation of the education system in Iran are equal to 2.793 and 0.550 respectively. Amongst the above factors, teaching approaches (Average $=3.113$ ) was evaluated better than others and the factor educational tools and facilities was weaker than other factors $($ Average $=2.385)$. The results of the mono-group T-test (table2) show that there is a significant difference between the current situation of 
the level of globalization in Iran and its current optimal global state ( $\mathrm{t} 356=-24.252 ; \mathrm{P}=0.001)$ or in other words, the situation is lower than the optimal level.

The sub scales teaching approaches, educational tools and facilities, curriculums and contents, and educational management are able to estimate the current situation of education system in Iran.

For this purpose, a multi-variable regression table was used. As it is seen in the table (3), the sub scales teaching approaches ( $\beta: 0.309$; sig:0.001), educational tools and facilities ( $\beta: 0.342$; sig:0.001), curriculums and contents ( $\beta: 0.344$; sig:0.001), and educational management ( $\beta: 0.0247$; sig:0.001) affect education system in Iran significantly and positively predict the current situation of education system in Iran.

In order to study the impacts of demographic characteristics of test subjects on their attitudes toward globalization of Iranian education system, we compare them according to these factors respectively.

Subjects' viewpoints towards globalization are different at various teaching age group. The results from the mono-variable analysis of variance (table4) demonstrate that the impact of subjects' teaching age group on the level of globalization is significant $(\mathrm{P}<0.05 ; \mathrm{F}(2.353)=4.086)$.

Based on Tukey's test (table5), there is no significant difference between primary with middle schools $(\mathrm{P}<0.05)$ and between primary and high schools $(\mathrm{P}<0.05)$; it was also found out that there existed significant difference between middle and high schools $(\mathrm{P}<0.05)$.

Now, we are going to analyze the level they are teaching and the level of globalization of education system in Iran.

As it is seen from the table 6 the level of globalization in middle schools are closer to its respective global condition (Post modern) $(\mathrm{M}=2.877)$ and the condition for high school is weaker $(\mathrm{M}=2.677)$.

Educators' education level affects the level of globalization of education system in Iran.The results from the mono-variable analysis of variance(table7)a show that the influence of subjects' education level is not significant on the level of globalization of education system in $\operatorname{Iran}(\mathrm{P}<0.05 ; \mathrm{F}(3.345)=0.224)$.

Subjects' administrative position influences the level of globalization of education system in Iran. Results of the one way analysis of variance (table8) show that the influence of subjects' administrative position on the level of globalization of education system in Iran is significant ( $\mathrm{P}=0.001 ; \mathrm{F}(3.345)=9.085)$.

By the help of Tukey's test(table9), no significant difference is observed between instructors' and principals' point of views about the level of globalization of education system in Iran $(\mathrm{P}<0.05)$; however, a significant difference is seen between teachers' and instructors' viewpoints $(\mathrm{P}<0.05)$ and the same applies to the difference teachers' and principals' point of views $(\mathrm{P}<0.05)$.

Now, we are going to study the placement of administrative position of educators based on the level of globalization of education system in Iran (Postmodern).

As it is seen in the table10, the situation for the level of globalization of education system in Iran amongst principals is closer to the current global situation (Postmodern) $(\mathrm{M}=2.945)$ and the respective situation for teachers is weaker $(\mathrm{M}=2.681)$.

Gender Affects the Level of Globalization of Education System in Iran

The results from the independent group T-test (table11) show that there is no significant difference between education system of Iran of two groups of men and women ( $\mathrm{t} 355=-0.690 ; \mathrm{P}=0.491)$ and both groups have perceived the level of globalization as negative.

\section{Conclusion}

The corresponding results of this analysis in a globalized and postmodernism education system indicated that their teaching approaches are based on discussion and argument, critical discussion, communal learning, initiative-oriented destructuralization, decentralization, analytical skills, and horizontal student-instructor relationship (Farmihani, 2010). Lyotard (2004). Believes that school relations are not merely based on logical dialogue but besides, focus on aesthetical aspects. He also suggests that the discussion parties do not communicate under a strict framework, but indeed, enter their sense of excitement and simply share their mental states. According to Daniel, education should give a particular attention to interaction and motivation that becomes possible by the help of communal learning and results in empathy. Education should establish a balance between independent and interactive learning (Bell, 1988).

Results of the analysis on educational tools and facilities in a globalized and postmodern education system indicated that using audio and visual equipment, specially computer and the Internet and laboratories play an important role in in-depth learning and availability of excursions and change of class formation pursuant to change of subject are of 
great significance.

Talking about Information Technology, Scrimshaw and McCormick (2001) in their article entitled 'Information and Communications Technology' consider pervasive interactions which are unique to postmodernism. These interactions provide the availability of infinite, multi-purpose relations for learners whose continuity assists in the formation of small and numerous societies in a school.

Findings from analyzing curriculums and contents in globalized and postmodern education system indicated that curriculums and contents is based on developmental education, considering individual differences amongst students and public culture as well as the possibility of multi-dimensional perception of the content, avoidance of general concepts, lack of stability and constant variation of content, participation and flexibility, practical and scientifical knowledge, and interdisciplinary curriculum. (Farmihani, 2010)

Postmodern curriculum should consider every student as a separate individual and take their needs into consideration; realization of this would not be simply possible in institutions like school that are similar to manufacturing firms and few special books are used (Farmihani, 2003)

Results obtained from analysis of school management represented that school management in a postmodern system is based on action research, long-term objectives, self-monitoring, leadership, and decentralization. (Farmihani, 2010)

Farrell regarded school in postmodern era as a dynamic and organic creature which has variable tensions and bonds with its minor and major components. (Farrel, 2000 )

As it is illustrated in table 1, the net average of education system of Ahwaz according to the globalization and postmodernism factors is equal to $\mathrm{M}=2.793$. Results of mono-group T-test (table2) suggested that there is a prominent gap between Ahwaz's education systems with the desired globalized one. In other words, the existing situation is lower than the desired level. Table 1 presented that the situation of all indicators is lower than the desired globalization level and in this aspect, teaching approaches with an average of 3.113 is the closest to the globalization level whereas educational tools and facilities with an average of 2.385 is the furthest from the globalization level.

As it was shown in table 3, the analyzed indicators are capable of evaluating the situation of education system in Iran and this is aligned with finding as well as Azad, Mahdi Azad's(2010) findings by electronic government analysis of education system in Ahwaz which was placed as in the second step (full-fledged) among five stages offered by United Nations research. Findings of this research are aligned with shahi, Shahi's(2006) findings regarding the mechanical structure of Khuzestan universities and centralization in management, governmental interventions with appointing principals, existence of traditional regulations and individual-centered management of those universities.

According to some Iranian researchers, most of the current challenges in Iranian education system are rooted in the contradiction between tradition and modernity. Conscious noticing these contradictions is needed such as emphasis on secularism in modern system whereas Iran has a religious society. Based on thorough study of indicators, it can be said that this challenge is because of the contradiction between tradition and modernity. Crisis is a definite issue and stopping in tradition in order to escape this contradiction in education system is not a solution and makes education bureau as an expired institution; whereas, one of the major objectives of Iranian education system is to obtain success and first rank in region and Islamic world. (Secretariat of Higher Education, 2010)

This type of system, which has a debatable proximity with the desired level, cannot lead to forerunning Iranian education system in the world. Iranian government introduces the policies in every aspect of providing education including financing, compilation, printing and dissemination of textbooks, educational environment, educational equipment, and training instructors whereas under the desirable circumstances of formal education system, comprehensive participation and balanced inference of individuals and other organs is emphasized (Secretariat of Higher Education, 2010)which can be considered as one of main reasons of the gap between the existing situation of Iranian education system and the desirable situation.

If these challenges remain and the education system does not seek their solutions, designated objectives won't be achieved and in order to fill this gap, one should use the many features of globalized education system that are outlines in postmodernism doctrines. In many circumstances where the modern doctrines were under crisis, postmodernism attempted to overcome those hardships by an improved approach. It should not be neglected that the researcher is not trying to imitate post modernity concepts, as there are still deficiencies even in post modernity but this matter is not an obstacle to use beneficial doctrines of postmodern. Now, the question is that whether the existing education system in Iran which is full of tradition and modern is able to utilize these reforms of postmodern or not? As Iran has not been fully complied the modern aspects and since postmodern is a historical and thinking 
condition, passing modern in order to reach postmodern is not essential. Although post moderns are still in their transmutation stage, they could successfully suggest solutions to overcome the existing crises in various aspects of modernity such as standardization, giving attention to contents of textbooks like religious, intense control form the side of those who possess the power and solutions such as destructuralization, decentralization, dialogue-centered, interdisciplinary sciences, and so on.

Therefore, based on the significant role that is played by education system in a country's circumstances, it is among the institutions that need to have the proper investment for planning of major indicators of this system to be aligned with the ones for globalization. This is possible regarding the good available potential in Iran including labor force, professional, and financial resources, and a quick pass of development steps is desirable.

In order to further the analysis of the situation of education system in Ahwaz, demographic properties of subjects of the test were investigated. The findings of the one-way variance analysis (table4) suggested that various teaching age group where instructors are working could have an impact on the level of proximity to the desired globalization factors.

In order to further this analysis, Tukey's post hoc test (table 5,6) was used. The results of which indicated that despite no significant differences between primary and middle schools as well as between middle and high schools, the difference between primary and high school is noticeable. Besides, further analysis of level regarding the net average showed that middle schools' situation is closer to globalization factors; however, the situation for high school is the furthest.

Results from the one-way variance analysis (table 7) demonstrated that education level of educators could not have any influence on closeness to globalization indices. To demonstrate this, it should be mentioned that on average the minimum degree of instructors is high-school diploma and the maximum is a Master's degree, unfortunately even those extra 6 years of studying in a university do not play any role in employing globalization factors and he acts similar to a instructor with diploma and the reason could be the centralized and standard system of education and structuralism.

Results from table 8 demonstrated that subjects' position resulted in differences between their viewpoints about the level of globalization of Iranian schools. Tukey's test (Table 9, 10) showed that there are no significant differences between in structures' and principals about globalization. In contrast, the differences were significant between principals with teachers and teachers with instructors. Further analysis suggested that teachers knew the existing education system further than it was supposed by principals who believed in the closeness of Iranian education system's situation with globalization indicators and for clarifying this, principals' in genuine viewpoint in addition to their confirmation of an ideal education system which indeed suggests an exaggeration arisen from their intention to regard their own job as a success are among these reasons. Results of the independent-group T-test (table 11) presented that gender could not play any role in the level of globalization and both men and women evaluated the level of globalization as negative. This consensus stands for the actual gap between the Iranian education system with globalization.

\section{References}

Albero, M. (2001). Global Era:The Sociology of Globalization. Translated into Persian by Nader Salar Zadeh Amiri. Azad Andishan Press, Tehran, 2004 (in Persain). Charlton and Andreas, 2006.

Azad, M. (2010). Analyzing the Electronic Government Model in Staff Department of Ahwaz Education Bureau. Master's Dissertation, Ahwaz: Chamran university

Bagheri, P. (2000). Introduction to Hegel's Philosophy. Journal of Arghanoon. No. 13. (in Persain).

Bell,D. (1988). Beyond Modernism.beyond self, Sociological Journey. London.Heinemann.

Charlton, B. G, \& Andras, p. (2006). Globalization in ScienceEducation: an Evitable and Beneficial Trend.Medical Hypotheses, Vol. 66. http://dx.doi.org/10.1016/j.mehy.2006.01.002

Derrida, J. (1974). Of Grammatology Trans. Gayatri Chakravorty, Spivak Baltimore. John Hopkins University Press. Farmaini Farahani, M. (2010). Post Modernism and Education System.Tehran, Ayeej Publications.

Farmihani Farahani, M. (2003). Studying Postmodernism Education Views with a Focus on Foucault and Derrida's Attitudes. Shahed University Bimonthly, Scientific \& Research Journal, 10th Year, No. 3.

Farrell, F.(2000). Postmodern and Education Marketing, Educational Management and Administration. Vol. 129, no. 2.

Ginkel, H. (2002). what Does Globalization Mean for Higher Education. Globalization: what Issues are at Stake for 
Universities, Universite Lavel; Quebec Canada.

Lyotard,J. Autumn. F. (2004). Pedagogical Implications of Postmodernity and its critics, Educational Innovations Quarterly. no. 9, p. 71

Madison, J. P. (2001). Globalization: Challenges and Opportunities. Translated by Mahmud Salimi, Rahbord Journal, Vol. 22 (in Persain).

McCormick, R, \& Scrimshaw, P. (2001).Information and Communications Technology, Knowledge and Pedagogy, Education.Vol. 1, no. 1.

Mehralizadeh, Y. (2005). "Globalization of Organizational Changes and Human Resource Development Planning", Ahwaz, University of Chamran. (in Persain).

Mushtaq, H. (2004). Globalization and Management Education in Developing Countries. [Online] Available: http://ideas.repec.org/p/pra/mprapa/29020.html (July 5, 2011)

Secretariat of Higher Education. (2010). Transformation Document Guideline for Formal Education System of Islamic Republic of Iran. Legislation Prospect 826.

Shahi, S, \& Naveh Ibrahim A, \& Mehralizadeh, Y.(2008). Higher Education Encountering Global Challenges in Khuzestan Universities. Higher Education Quarterly, no. 50, pp. 19-45,

Shahi,s.(2006). Investigating Organizational Communication Structure in Graduate Studies in the Path to Globalization. Ph.D. Graduation Work in Khuzestan,Iran.

Table 1. the results obtained from the average, standard deviation and rank (descriptive) of education system in Iran based on Post modern indicators (Global Education System)

\begin{tabular}{|l|l|l|l|}
\hline Education System in Iran & Average & Standard Deviation & Rank \\
\hline Teaching Approaches & 3.113 & 0.676 & 1 \\
\hline Educational Tools and Facilities & 2.385 & 0.745 & 4 \\
\hline Curriculums and Contents & 2.726 & 0.767 & 3 \\
\hline Educational Management & 2.928 & 0.542 & 2 \\
\hline Total (Education System in Iran) & 2.793 & 0.550 & \\
\hline
\end{tabular}

To define the T-value, firstly, the average and the standard deviation should be added and results in 3.343 that for the ease of calculation, we round it as 3.5 and take it as the cutting line of desirable situation.

Table 2. The mono-group T-test

\begin{tabular}{|l|l|l|l|l|}
\hline \multirow{2}{*}{ Education System of Iran } & \multicolumn{4}{|l|}{$\mathrm{T}$ value=3.5 } \\
\cline { 2 - 5 } & $\mathrm{T}$ & $\begin{array}{l}\text { Freedom } \\
\text { degree }\end{array}$ & $\begin{array}{l}\text { Significance } \\
\text { level }\end{array}$ & $\begin{array}{l}\text { Average } \\
\text { difference }\end{array}$ \\
\hline & -22.252 & 356 & 0.001 & -0.706 \\
\hline
\end{tabular}

Table 3. Multi-variable regression table for predicting the current situation of education system in Iran from the sub scales teaching approaches, educational tools and facilities, curriculums and contents, and educational management.

\begin{tabular}{|l|l|l|l|l|l|}
\hline \multirow{2}{*}{ Variable } & \multicolumn{5}{|l|}{ Dependent Variable: Education System in Iran } \\
\cline { 2 - 3 } & $\mathrm{B}$ & $\beta$ & $\mathrm{R}$ & Square R & sig \\
\hline Teaching Approaches & 0.252 & 0.309 & & & 0.001 \\
\hline Educational Tools and Facilities & 0.252 & 0.342 & \multirow{3}{*}{0.999} & 0.99 & 0.001 \\
\hline Curriculums and Contents & 0.247 & 0.344 & & & 0.001 \\
\hline Educational Management & 0.251 & 0.0247 & & & 0.001 \\
\hline
\end{tabular}


Table 4. One Way Analysis of Variance

\begin{tabular}{|l|l|l|l|l|l|}
\hline Statistical Indicators & $\begin{array}{l}\text { Sum of Square } \\
\text { Roots }\end{array}$ & $\begin{array}{l}\text { Freedom } \\
\text { Degrees }\end{array}$ & $\begin{array}{l}\text { Average of } \\
\text { Square Roots }\end{array}$ & F & $\begin{array}{l}\text { Significance } \\
\text { Level }\end{array}$ \\
\cline { 1 - 4 } Source of Changes & 2.44 & 2 & 1.22 & \multirow{2}{*}{4.086} & 0.018 \\
\cline { 1 - 4 } Inter-group & 105.417 & 353 & 0.299 & & \\
\hline Total & 2886.627 & 356 & & & \\
\hline
\end{tabular}

Table 5. Results of the Tukey's test

\begin{tabular}{|l|l|l|l|}
\hline Difference between Groups & $\begin{array}{l}\text { Difference of } \\
\text { Average }\end{array}$ & Error Standard Deviation & $\begin{array}{l}\text { Significance } \\
\text { Level }\end{array}$ \\
\hline Primary with Middle Schools & -0.0488 & 0.07099 & 0.771 \\
\hline Primary with High Schools & 0.1506 & 0.0692 & 0.077 \\
\hline Middle with High Schools & 0.1994 & 0.07338 & 0.020 \\
\hline
\end{tabular}

Table 6. the following table represents the average and the standard deviation of teaching approaches by the separation of teaching age group.

\begin{tabular}{|l|l|l|l|}
\hline Teaching age group & Average & Standard Deviation & Rank \\
\hline Primary School & 2.828 & 0.615 & 2 \\
\hline Middle Schools & 2.877 & 0.682 & 1 \\
\hline High Schools & 2.677 & 0.476 & 3 \\
\hline
\end{tabular}

Table 7. One Way Analysis of Variance

\begin{tabular}{|c|c|c|c|c|c|}
\hline $\begin{array}{l}\text { Statistical Indicators } \\
\text { Source of Changes }\end{array}$ & $\begin{array}{l}\text { Sum of Square } \\
\text { Roots }\end{array}$ & \begin{tabular}{l|} 
Freedom \\
Degrees
\end{tabular} & $\begin{array}{l}\text { Average of } \\
\text { Square Roots }\end{array}$ & $\mathrm{F}$ & $\begin{array}{l}\text { Significance } \\
\text { Level }\end{array}$ \\
\hline Inter-group & 0.137 & 2 & 0.068 & \multirow{3}{*}{0.224} & \multirow{3}{*}{0.80} \\
\hline Intra-group & 105.502 & 345 & 0.306 & & \\
\hline Total & 2814.932 & 348 & & & \\
\hline
\end{tabular}

Table 8. One Way Analysis of Variance

\begin{tabular}{|c|c|c|c|c|c|}
\hline $\begin{array}{l}\text { Statistical Indicators } \\
\text { Source of Changes }\end{array}$ & $\begin{array}{l}\text { Sum of Square } \\
\text { Roots }\end{array}$ & $\begin{array}{l}\text { Freedom } \\
\text { Degrees }\end{array}$ & $\begin{array}{l}\text { Average of } \\
\text { Square Roots }\end{array}$ & $\mathrm{F}$ & $\begin{array}{l}\text { Significance } \\
\text { Level }\end{array}$ \\
\hline Inter-group & 5.267 & 2 & 2.633 & \multirow{3}{*}{9.085} & \multirow{3}{*}{0.001} \\
\hline Intra-group & 102.611 & 354 & 0.29 & & \\
\hline Total & 2893.633 & 357 & & & \\
\hline
\end{tabular}

Table 9. Results of the Analysis of Tukey's test

\begin{tabular}{|l|l|l|l|}
\hline Difference between Groups & Difference of Average & Error Standard Deviation & Significance Level \\
\hline Instructor with Teacher & 0.2373 & 0.06115 & 0.001 \\
\hline Instructor with Principal & -0.0274 & 0.10253 & 0.961 \\
\hline Teacher with Principal & -0.2647 & 0.0989 & 0.021 \\
\hline
\end{tabular}


Table 10. The following table represents the average and the standard deviation of the level of globalization based on different administrative positions.

\begin{tabular}{|l|l|l|l|}
\hline Administrative Position & Average & Standard Deviation & Rank \\
\hline Instructor & 2.918 & 0.539 & 2 \\
\hline Teacher & 2.681 & 0.542 & 3 \\
\hline Principal & 2.945 & 0.509 & 1 \\
\hline
\end{tabular}

Table 11. Gender Affecting the Level of Globalization of Education System in Iran

\begin{tabular}{|l|l|l|l|l|l|l|l|}
\hline Variable & Group & Number & Average & $\begin{array}{l}\text { Standard } \\
\text { Deviation }\end{array}$ & $\mathrm{t}$ & $\begin{array}{l}\text { Significance } \\
\text { Level }\end{array}$ & $\begin{array}{l}\text { Freedom } \\
\text { Degree }\end{array}$ \\
\hline \multirow{2}{*}{$\begin{array}{l}\text { Level of } \\
\text { Globalization }\end{array}$} & Men & 113 & 2.763 & 0.517 & \multirow{2}{*}{-0.690} & 0.491 & 355 \\
\cline { 2 - 6 } & Women & 224 & 2.807 & 0.566 & -690 & 35 \\
\hline
\end{tabular}

